
A
$\mathrm{R}$
$\mathrm{T}$
Y
K
$\mathrm{U}$
七

\title{
Typologia sygnetów drukarskich (na przykładzie znaków stosowanych przez polskich impresorów od XV do połowy XVII wieku)
}

Streszczenie. Celem niniejszego artykułu jest przedstawienie typologii sygnetów drukarskich stosowanych przez impresorów działających na ziemiach polskich od XV do połowy XVII stulecia, a zatem od momentu, gdy ów element wytłoczony został w polskim druku po raz pierwszy, do chwili, gdy polska typografia (a wraz z nią i sygnet) przeżywać zaczęły wyraźny kryzys. Wydzielony tymi ramami chronologicznymi zbiór liczy ponad 100 znaków impresorskich, a zatem na tyle dużo, by potrzebne, a wręcz konieczne, było jego uporządkowanie.

Metoda, która pozwala uczynić to możliwie najprzejrzyściej, jest wyodrębnienie w ramach przedmiotu badań poszczególnych typów, co odbywa się na podstawie odpowiednio dobranych kryteriów. Odpowiednio, czyli tak, by uwzględniały każdy aspekt badanej materii i pozwalały na ukazanie jej w sposób jak najpełniejszy. W przypadku sygnetów drukarskich kryteria te muszą mieć nade wszystko na względzie fakt, że godła impresorskie są nie tylko elementami typograficznymi, ale i graficznymi, co powoduje, że rozpatrywać je należy w świetle zarówno typografii (czy szerzej bibliologii), jak i sztuki graficznej. Wziąwszy to pod uwagę, bogaty i wielce zróżnicowany zespół, jaki tworzą polskie sygnety używane od XV do połowy XVII wieku, uporządkować można na podstawie trzech kryteriów: chronologicznego, ikonograficznego i związanego z morfologią książki.

SŁOwA KLUCzowe: sygnet drukarski, typologia, polska typografia od XV do połowy XVII wieku

Jedną z istotniejszych, a zarazem przysparzającą najwięcej problemów, czynności badawczych wchodzących w zakres badań naukowych jest systematyzacja analizowanego materiału, czyli porządkowanie go za pomocą tak dobranych kryteriów, by uwzględniały każdy aspekt badanej materii i pozwalały na ukazanie jej w sposób jak najpełniejszy. Metodą pozwalającą 
uczynić to możliwie najczytelniej jest wyodrębnienie $\mathrm{w}$ ramach przedmiotu badań poszczególnych typów, a zatem opracowanie pewnego systemu typologicznego, który winien odznaczać się przede wszystkim prostota przejrzystością i zgodnością z zasadami logiki. Największą trudność w stworzeniu poprawnej typologii sprawia dobór takich kryteriów, które możliwie najtrafniej zdołają oddać różnorodność relacji wiążących poszczególne elementy badanego zbioru oraz uporządkują je w jasny i czytelny sposób. Dobór kryteriów każdorazowo uwarunkowany jest charakterem i specyfiką przedmiotu badań. Każda materia wymaga bowiem indywidualnego potraktowania, co przejawia się właśnie w wyborze odmiennych podstaw porządkowania ${ }^{1}$.

Tym większy zatem problem, gdy przedmiot systematyzacji ma tak złożoną naturę, że konieczne staje się rozpatrywanie go przez pryzmat więcej niż jednej dziedziny, a tak właśnie jest w przypadku sygnetów drukarskich, czyli znaków, którymi swoje druki firmowali dawni impresorzy. $Z$ racji specyficznego charakteru tychże znaków trzeba je bowiem zaliczyć do elementów zarówno typograficznych, jak i graficznych, wobec czego analizować je należy w świetle nie tylko typografii, czy nawet szerzej, bibliologii, ale również sztuki graficznej².

Na uwagę zasługuje fakt, że owa dwoista natura cechowała impresorskie godła od początku ich istnienia i to pomimo tego, iż powołano je do życia bynajmniej nie w celu zdobienia druków, ale z powodów bardziej prozaicznych, właściwie czysto praktycznych. Pierwotną i zasadniczą funkcja, którą sygnet miał pełnić w druku, było bowiem informowanie nabywców książki o tym, w której powstała oficynie. Oddziałując niczym współczesne logo, znak typografa zabezpieczał zyski płynące ze sprzedaży sygnowanej nim książki na rzecz konkretnej łłoczni, a niejako przy okazji reklamował również jej działalność wydawniczą ${ }^{3}$. To czysto praktyczne zadanie już jednak przez samych pomysłodawców sygnetu, czyli Johanna Fusta i Petera Schöffera ${ }^{4}$, zostało przydzielone elementowi o tak

${ }^{1}$ Zob. m.in. J. Kębłowski, Klasyfikacja sztuk plastycznych, w: Wstęp do historii sztuki, red. P. Skubiszewski, t. 1: Przedmiot - metodologia - zawód, Warszawa 1973, s. 69106; A. Żbikowska-Migoń, Typologia oświeceniowej ksiażki naukowej i jej model edytorski, w: Ksiażka naukowa w kulturze polskiego Oświecenia, Wrocław 1977, s. 63-70; M. Komza, Zdobione karty tytułowe. (Wprowadzenie do typologii na przykładzie siedemnastowiecznej ksiażki gdańskiej), „Studia o Książce” 1978, t. 8, s. 51-67; K.M. Kowalski, Zagadnienia typologii i kwestionariusza badawczego, w: idem, Polskie źródła ikonograficzne XVII wieku. Analiza metodologiczna, Warszawa-Poznań 1998, s. 51-82.

${ }^{2}$ K. Krzak-Weiss, Polskie sygnety drukarskie od XV do połowy XVII wieku, Poznań 2006, s. 9 i passim.

${ }^{3}$ Ibidem, s. 22-25, 44.

${ }^{4}$ Można jedynie przypuszczać, że wprowadzenie po raz pierwszy do użytku sygnetu drukarskiego właśnie przez Fusta i Schöffera spowodowane było ich przemoż- 
rozbudowanej i ciekawej formie, że zakres jego „obowiązków” poniekąd mimowolnie i od razu rozszerzył się o funkcję dekoracyjną. I choć ta ostatnia w jednych znakach rozwinięta była bardziej niż w innych, to nie sposób nie dostrzec jej w którymkolwiek z nich. Dotyczy to również godeł stosowanych przez polskich impresorów. Warto w tym miejscu podkreślić, że zwyczaj sygnowania druków przyjął się w polskiej typografii stosunkowo wcześnie, bo już w 1475 roku, za sprawą Kaspra Straubego, który swój znak rozpoznawczy umieścił w kolofonie Opus restitutionum, usurarum et excommunicationum Plateanusa ${ }^{5}$. Jego śladem szybko podążyli kolejni drukarze, ich godła do połowy XVII stulecia - momentu będącego niezwykle istotną cezurą w dziejach zarówno sygnetu, jak i polskiej typografii w ogóle - stworzyły całkiem pokaźny, bo liczący ponad 100 godeł, zbiór ${ }^{6}$.

nym pragnieniem zaakcentowania, że Psałterz moguncki (1457), w którym owo godło umieścili, wytłoczony został bezsprzecznie przez nich, choć materiał typograficzny wskazywałby na Johanna Gutenberga, którego warsztat wraz z wyposażeniem krótko wcześniej przejęli. Zob. H. Szwejkowska, Ksiażka drukowana XV-XVIII wieku. Zarys historyczny, wyd. 2 przejrzane i uzup., Wrocław-Warszawa 1975, s. 19. Takie wyjaśnienie (choć z braku dowodów niestety tylko hipotetyczne) pozwalałoby jednak na ostateczne rozwiązanie dylematu, który druk był w istocie pierwszym sygnowanym zdaniem niektórych badaczy to dopiero Biblia z 1462 roku, ta zaś powstała już na podstawie nowego materiału typograficznego. Por.: E. Weil, Die Deutschen Druckzeichen des XV. Jahrhunderts, München 1929, s. 16; H. Grimm, Deutsche Buchdruckersignete des XVI. Jahrhunderts. Geschichte, Sinngehalt und Gestaltung kleiner Kulturdokumente, Wiesbaden 1965, s. 15; Encyklopedia wiedzy o ksiażce, red. A. Birkenmajer, B. Kocowski, J. Trzynadlowski, Wrocław 1971, szp. 2258; G.A. Glaister, Encyclopedia of the Book, London 1966, s. 136.

${ }^{5}$ Wprawdzie od wytłoczenia pierwszego sygnetu drukarskiego należącego do Fusta i Schöffera do chwili wprowadzenia owego elementu do polskich druków upłynęło blisko 20 lat, ale przez pierwszych kilka lat nikt, poza samymi pomysłodawcami, nie znakował swych wydawnictw i sytuacja taka utrzymała się aż do roku 1471, kiedy to swego godła użył Arnoldus Ter Hoernen (Therhoernen) z Kolonii. W 1474 roku swoje druki sygnować zaczął kolejny, ale tylko jeden, typograf - Nicolaus Gotz z Kolonii, za to rok 1475, w którym swój znak wytłoczył Kasper Straube, okazał się przełomowy, ponieważ oprócz niego godła wprowadziło wówczas do użytku jeszcze czterech drukarzy (Andreas Frisner i Johann Sensenschmidt z Norymbergi oraz Johann de Westphalia i Johann Veldener z Louvain). Zob. K. Krzak-Weiss, Polskie sygnety..., s. 16 (tam również odwołania do zagranicznej literatury przedmiotu), 95-98.

${ }^{6}$ Powodem przyjęcia połowy XVII stulecia jako granicy chronologicznej dla prowadzonych badań był panujący wówczas wyraźny kryzys polskiej typografii, który znalazł odzwierciedlenie również w dziejach sygnetu drukarskiego. Przyczyn owego kryzysu należy zaś upatrywać przede wszystkim w kryzysie miast spowodowanym zmianą sytuacji gospodarczo-społecznej (przekształcenia z rzeczypospolitej szlacheckiej w oligarchię) oraz w hamujących rozwój kultury rozlicznych działaniach wojennych. Zob. ibidem, s. 11, 45-49. 
Zbiór na tyle bogaty i różnorodny, że wymagający systematyzacji. W jej przeprowadzeniu niemałą pomocą służyć mogą zagraniczne opracowania poświęcone zagadnieniu sygnetów drukarskich. Ich analiza nie tylko pozwoli wskazać kierunki porządkowania materiału badawczego obejmującego znaki polskich impresorów, ale nade wszystko uwydatni podstawowy problem, jaki ów materiał sprawia, a mianowicie trudność jasnego sformułowania jednego systemu typologicznego. Systemu, który byłby na tyle uniwersalny, aby można go stosować do wszystkich zbiorów znaków drukarskich niezależnie od czasu i miejsca ich powstania.

Tymczasem niemalże w każdym opracowaniu poświęconym znakom impresorskim odkryć można odmienny sposób systematyzacji. Co więcej, różniące się między sobą metody proponują nawet ci badacze, którzy opisują i analizują ten sam materiał badawczy. Tak jest między innymi w przypadku autorów dwóch monografii poświęconych niemieckim sygnetom drukarskim. W pierwszej z nich, autorstwa Annemarie Meiner7, zastosowany został system bardziej złożony. Sposób porządkowania obszernego materiału badawczego zakłada bowiem jednoczesne użycie dwóch kryteriów: chronologicznego, uznanego za nadrzędne, oraz podporządkowanego mu - ikonograficznego. W efekcie zebrany przez badaczkę materiał podzielony został najpierw na cztery główne działy, obejmujące znaki stosowane w konkretnych przedziałach czasowych ${ }^{8}$, po czym w ramach każdego z tych działów - tym razem na podstawie cech ikonograficznych badanych godeł - wyszczególnione zostały poddziały. Powstała w ten sposób konstrukcja nieodparcie nasuwa skojarzenie z układem działowym, będącym jednym z kilku możliwych sposobów porządkowania opisów bibliograficznych w obrębie bibliografii ogólnej. I tak na przykład w pierwszym z działów - zestawiającym znaki z doby inkunabułów wyszczególnione zostały $\mathrm{w}$ ramach oddzielnych poddziałów: sygnety o charakterze znaków handlowych, sygnety z motywami związanymi z życiem codziennym i z rzemiosłem, sygnety o tematyce religijnej i mistycznej, sygnety z motywami baśniowymi oraz sygnety o charakterze herbowym9. W pozostałych trzech głównych działach zarówno liczba poddziałów, jak i ich zawartość są nieco inne, co z pewnością jest skutkiem odmiennych cech ikonograficznych ujętych w nich znaków.

${ }^{7}$ A. Meiner, Das Deutsche Signet. Ein Beitrag zur Kulturgeschichte, Leipzig 1922.

${ }^{8}$ Poddany analizie materiał badawczy podzielony został przez Annemarie Meiner na następujące zasadnicze działy: Sygnety doby inkunabułów (1457-ok. 1500), Czas sygnetów (1500-ok. 1555), Sygnety późnorenesansowe (ok. 1555-ok. 1640) oraz Sygnety z czasów kryzysu niemieckiej typografii (ok. 1640-ok. 1890). Zob. ibidem, passim.

${ }^{9}$ Ibidem, s. 11-19. 
Z kolei Heinrich Grimm, który poddał analizie ten sam (choć węższy pod względem zasięgu chronologicznego) co Meiner materiał badawczy, oparł przyjęty $\mathrm{w}$ swym opracowaniu sposób systematyzacji tylko i wyłącznie na ikonografii ${ }^{10}$. Tym samym, zamiast ujęcia diachronicznego, które pokazałoby ewolucję sygnetów w konkretnym ( $w$ tym przypadku ograniczonym do XVI stulecia) przedziale czasu, zaproponował spojrzenie niezależne od chronologii, a skupione na motywach plastycznych, zdobiących poszczególne sygnety ${ }^{11}$.

Jaką wobec tego metodę należałoby obrać w odniesieniu do godeł polskich impresorów? Fragmentaryczną odpowiedź na to rudymentarne pytanie znaleźć można w monografii tychże znaków, w której ułożone zostały one w kolejności chronologicznej, ponieważ ta gwarantowała największą czytelność i klarowność analizy ${ }^{12}$. Dla celów tego opracowania materiał badawczy (obejmujący znaki stosowane od XV do połowy XVII stulecia) podzielony został na trzy mniejsze grupy: 1 . Sygnety drukarskie pierwszych impresorów; 2. Sygnety polskich typografów XVI stulecia; 3. Polskie sygnety drukarskie w pierwszej połowie XVII wieku. Taki podział wynikał przede wszystkim z uwzględnienia zmieniającej się na przestrzeni dwóch stuleci sytuacji polskiej typografii, i choć podówczas był wystarczający, to na pewno nie wyczerpał możliwości systematyzacyjnych, które przynosił zgromadzony materiał badawczy. Niniejsza typologizacja będzie zatem próbą kolejnego (może już ostatecznego?) wykorzystania tych możliwości. Tym razem za kryteria porządkowania przyjęte zostana, obok chronologii, także ikonografia oraz morfologia książki.

${ }^{10}$ H. Grimm, op.cit., s. 3. Kryterium ikonograficzne przyjęte zostało także przez innych badaczy zajmujących się zagadnieniem sygnetów drukarskich, m.in. przez Douglasa McMurtriego (Printers' Mark, w: The Book. The Story of Printing \& Bookmaing, New York 1937, s. 289-303) oraz Williama Robertsa (Printers' Mark, London 1893, s. 3-39).

${ }^{11} \mathrm{~W}$ wypadku opracowań poświęconych sygnetom drukarskim stosowanym przez typografów z kilku państw najlepiej jest, jeśli materiał badawczy porządkuje się na podstawie kryterium terytorialnego, ponieważ pozwala to na uzyskanie czytelnego obrazu znaków używanych w poszczególnych ośrodkach. (Zob. W. Roberts, op.cit., passim). Jest to tym cenniejsze, że wraz z popularyzacją sygnetów drukarskich nastąpił proces nadawania im swoiście narodowych cech. Zob. K. Krzak-Weiss, Polskie sygnety..., s. 31-33. Z kolei Hugh William Davies, autor obszernej pracy poświęconej sygnetom stosowanym w różnych ośrodkach europejskich w latach 1457-1560, przyjął w swym dziele (a dokładniej w dołączonym do niego katalogu) układ ikonograficzny, który nie dał już tak przejrzystego obrazu całości jak w przypadku pracy Robertsa. Zob. H.W. Davies, Devices of the early printers 1457-1560. Their history and development with a chapter on portrait figures of printers, London 1935.

${ }^{12}$ Zob. K. Krzak-Weiss, Polskie sygnety..., s. 35-49. 
Ponowne użycie kryterium chronologicznego nie oznacza jednak powtórzenia wcześniejszego podziału, lecz stanowi punkt wyjścia do opracowania bardziej złożonego układu typów, nawiązującego wyraźnie do graficznej natury sygnetów drukarskich. Sygnetów, które od momentu pojawienia się $\mathrm{w}$ polskich drukach do połowy XVII stulecia, kiedy to z wolna zaczęły tracić na znaczeniu, podlegały wyrazistym przemianom stylistycznym. Kryterium chronologiczne jest więc w tym przypadku nierozerwalnie związane z kryterium stylistyczno-formalnym, które pozwala wyróżnić wśród znaków polskich impresorów: 1) znaki o cechach późnośredniowiecznych, 2) znaki renesansowe, 3) znaki manierystyczne oraz 4) znaki barokowe.

Do pierwszych $z$ nich, stosowanych pod koniec XV i w początkach XVI stulecia, zaliczyć należałoby te godła, które odznaczają się używaniem sztywnej, mało różnicowanej pod względem grubości, kreski konturowej oraz płaskim modelunkiem. W grupie tej znalazłyby się zatem sygnety: Kaspra Straubego, Szwajpolta Fiola, Kaspra Hochfedera, a także Jana Hallera ${ }^{13}$. Cechą znaków renesansowych, których stosowanie datuje się na lata około $1518-1550^{14}$, jest natomiast umiejętnie różnicowana, delikatniejsza i zdecydowanie bardziej miękko prowadzona kreska oraz wprowadzający efekt plastyczności szrafirunek. Od wcześniej stosowanych godeł odróżnia je także zupełnie inny charakter ornamentyki, w której prym wiodą typowe dla renesansu formy antykizujące. Do tej kategorii znaków zaliczyć bez wątpienia należy sygnety Floriana Unglera (dwa wprowadzone jako ostatnie spośród pięciu, jakich w ogóle używał), wdowy po nim - Heleny (il. 1) oraz Hieronima Wietora ${ }^{15}$. Kolejną grupę godeł tworzą te, w których nad renesansowymi cechami stylistyczno-formalnymi przeważać zaczynają cechy manierystyczne, co zaobserwować można już w połowie XVI stulecia, a co widoczne jest zarówno w sposobie opracowania drzeworytowych klocków ciętych odtąd bardzo cienką kreską i z użyciem delikatnego cieniowania (upodabniającego do miedziorytów), jak również w bogactwie i specyficznym charakterze ornamentyki (np. w popularnym ornamencie zwijanym i okuciowym $)^{16}$. Znakomity-

${ }^{13}$ Ibidem, s. 95-107.

${ }^{14}$ Za początek fazy sygnetów renesansowych przyjęłam datę rozpoczęcia pracy przez krakowską oficynę Hieronima Wietora, która pierwsza wprowadziła do użytku zarówno sygnety, jak również inne elementy wyposażenia graficznego o formach nowożytnych. Zob. ibidem, s. 52-54. Periodyzacja ta pokrywa się z propozycjami chronologizacyjnymi Ewy Chojeckiej dotyczącymi polskiej grafiki ilustracyjnej. Zob. E. Chojecka, Ilustracja polskiej książki drukowanej, Warszawa 1980, s. 23.

${ }^{15}$ K. Krzak-Weiss, Polskie sygnety..., s. 113-119.

${ }^{16}$ Ibidem, s. 55-56. 
Il. 1. Samuel Maciejowski, Sermo in funere Sigismundi I regis Poloniae, Kraków 1548. Karta tytułowa z sygnetem o charakterze bordiurowym należącym do Heleny Unglerowej. (Księgozbiór Biblioteki Uniwersyteckiej w Poznaniu, SD 229660 I)

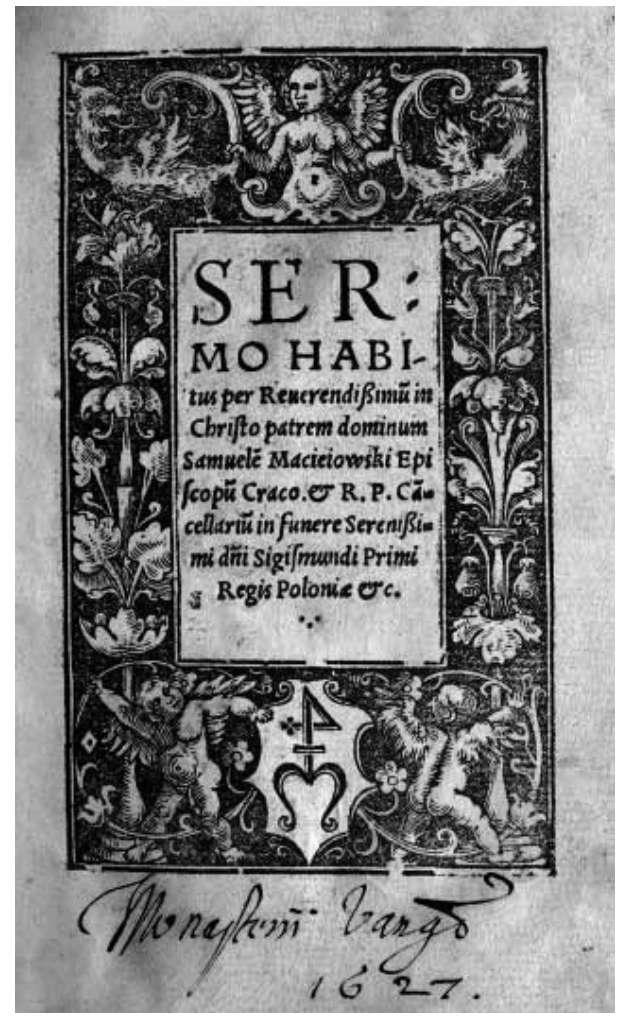

mi egzemplifikacjami tych przemian są znaki m.in. Mikołaja i Stanisława Szarfenbergerów, Macieja Wirzbięty czy Mateusza Siebeneichera, ale także znaki innych typografów z tego okresu (a warto dodać, że był to czas rozkwitu impresorskich godeł) doskonale wpisują się w ów nurt ${ }^{17}$. Ostatnią grupę, z wydzielonych dzięki zastosowaniu kryterium chronologicznego i stylistyczno-formalnego, tworzą sygnety używane w pierwszej połowie XVII stulecia. Wprawdzie w pierwszych latach tego okresu wciąż jeszcze przeważają w nich formy manierystyczne, jednakże z wolna ustępują one miejsca nowej, barokowej stylistyce, której przejawem jest przede wszystkim bogata ornamentyka. Niestety, ani obfitości, ani różnorodności zdobień nie towarzyszy wówczas dobra, a nawet zadowalająca jakość opracowania sygnetowych drzeworytów, w których dominantami są grube i nieporadnie cięte kreski. Tę wyraźnie schyłkową fazę w dziejach godeł impresorskich (a także innego typu wyposażenia graficznego) reprezentują znaki m.in. Szymona Kempiniego i Krzysztofa Schedla ${ }^{18}$.

${ }^{17}$ Ibidem, s. 56, 127-142.

${ }^{18}$ Ibidem, s. 176-177, 190-191. 
Równie istotną podstawą klasyfikacji, co chronologia, jest bez wątpienia kryterium ikonograficzne, zresztą pozostające $\mathrm{z}$ nią $\mathrm{w}$ ścisłym związku. Wraz bowiem z upływającym czasem zmieniała się moda na motywy przedstawieniowe obierane przez typografów za znaki rozpoznawcze ich oficyn, w związku z czym te, które cieszyły się popularnością w początkach istnienia sygnetów, już w dobie ich rozkwitu były passé. I choć o tym związku pamiętać trzeba, to żeby uniknąć tworzenia skomplikowanych, wzajemnie przenikających się systemów porządkowania oraz z uwagi na mnogość typów, które można wyróżnić dzięki kryterium ikonograficznemu, wydaje się, że zdecydowanie lepszym rozwiązaniem niż połączenie go z wcześniej omawianym jest przeprowadzenie systematyzacji całkowicie niezależnej.

Przyjmując wobec powyższego za podstawę porządkowania tylko i wyłącznie tematykę kompozycji, sygnety używane przez polskich typografów od XV do połowy XVII stulecia podzielić można na:

1) monogramowe (die Monogrammsignete) ${ }^{19}$, czyli te, w których wiodącym elementem kompozycyjnym są monogramy typografa - doskonałe przykłady stanowią m.in. godła firmowe Jana Hallera (il. 2) i Floriana Unglera ${ }^{20}$;

2) herbowe (die Wappensignete) ${ }^{21}$, czyli znaki, których cechą charakterystyczną jest obecność herbu albo samodzielnie pełniącego funkcję godła impresorskiego, albo będącego jednym z wielu jego elementów kompozycyjnych. Do tego typu sygnetów zaliczyć należy przede wszystkim godło Kaspra Straubego 22 - pierwszego polskiego typografa, który „podpisywał” swoje druki, a czynił to za pomocą dwóch tarcz herbowych ( $\mathrm{z}$ widniejącymi nań nomina sacra) zawieszonych na pojedynczej gałązce ${ }^{23}$. Dwoisty charakter herbów zdobiących nieco późniejsze sygnety należące do tej kategorii pozwa-

${ }^{19}$ Sygnety monogramowe cieszyły się największą popularnością w dobie inkunabułów, a najliczniejszą grupę ich użytkowników tworzyli typografowie francuscy i angielscy. Zob. A. Meiner, op.cit., s. 30-32, 64-65; W.J. Meyer, Die französischen Drucker- und Verlegerzeichen des XV. Jahrhunderts, München 1926, s. 19-22 i passim; R. Juchhoff, Drucker- und Verlegerzeichen des XV. Jahrhunderts in den Niederlanden, England, Spanien, Böhmen, Mähren und Polen, München 1927, s. 62-64, 67-70.

${ }^{20}$ K. Krzak-Weiss, Polskie sygnety..., s. 106, 113.

${ }^{21}$ A. Meiner, op.cit., s. 17-19, 32-35, 67.

${ }^{22}$ K. Krzak-Weiss, Polskie sygnety..., s. 95-98.

${ }^{23}$ Warto zauważyć, że sygnet drukarski Kaspra Straubego wykazuje wyraźne pokrewieństwo z godłem firmowym należącym do pomysłodawców sygnowania Fusta i Schöffera. Tym samym doskonale wpisuje się w nurt panujący powszechnie w początkowej fazie istnienia znaków impresorskich, kiedy to niemal każdy z typografów posługujący się sygnetem opierał jego kompozycję (w mniejszym lub większym stopniu) na godle inicjatorów sygnowania. 
Il. 2. Jan Łaski, Commune Poloniae Regni Privilegium, Kraków 1506. Sygnet oficyny Jana Hallera. (Księgozbiór Biblioteki Uniwersyteckiej w Poznaniu, SD 188 III)

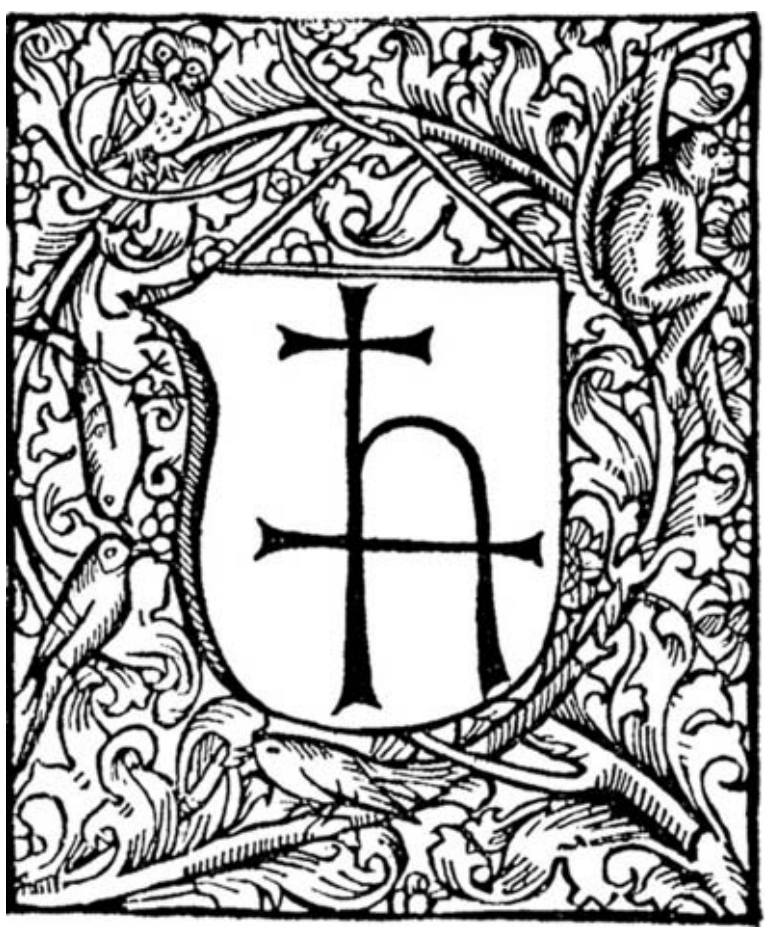

la na wydzielenie $\mathrm{w}$ jej obrębie dwóch mniejszych podgrup, które obejmują: a) sygnety z herbami miejskimi oraz b) sygnety z herbami rodowymi. W pierwszej z nich znajdą się na pewno znaki Szwajpolta Fiola i Floriana Unglera ${ }^{24}$, na których widnieje herb miejski Krakowa, a także godła Kaspra Hochfedera i Jana Hallera ${ }^{25}$, na których obok godła Krakowa znajdują się też herby Polski i Litwy. Do drugiej z podgrup zaliczyć natomiast należy sygnety Mikołaja i Stanisława Szarfenbergerów ${ }^{26}$ - w znaku firmowym swej oficyny mieścili nadany im w roku 1554 herb Półkozic ${ }^{27}$, oraz Cypriana Bazylika ${ }^{28}$, który swe nazwisko i herb zawdzięczał Heraklidesowi Jakubowi Bazilikosowi ${ }^{29}$;

${ }^{24}$ K. Krzak-Weiss, Polskie sygnety..., s. 99-100, 110.

${ }^{25}$ Ibidem, s. 102-104.

${ }^{26}$ Ibidem, s. 127-137.

${ }^{27}$ Problem nobilitacji Szarfenbergów wyjaśnił obszerniej Aleksander Birkenmajer. Zob. A. Birkenmajer, Nobilitacja Szarffenbergerów, w: idem, Studia bibliologiczne. Wybór tekstów, red. H. Więckowska, A. Birkenmajer, Wrocław 1975, s. 313-331.

${ }^{28}$ K. Krzak-Weiss, Polskie sygnety..., s. 149-150.

${ }^{29}$ Drukarze dawnej Polski od XV do XVIII wieku, z. 5: Wielkie Księstwo Litewskie, oprac. A. Kawecka-Gryczowa, K. Korotajowa, W. Krajewski, Wrocław 1959, s. 45. 
3) sygnety z wizerunkami świętych ${ }^{30}$ - a konkretnie św. Stanisława oraz św. Floriana, których wyobrażenia stanowiły główne elementy kompozycyjne dwóch godeł firmowych należących do Floriana Unglera $^{31}$;

4) emblematyczne, czyli zdobione motywami inspirowanymi przez Emblematum liber Andreasa Alciatusa oraz inne zbiory emblematyczne, bardzo popularne szczególnie w drugiej połowie XVI oraz w XVII wieku. Wprawdzie kompozycje sygnetowe odbiegały nieco od klasycznego modelu emblematu, gdyż zawierały zazwyczaj tylko dwie z jego części składowych (tj. lemmat oraz icon, bez subskrypcji), niemniej jednak nawet w tej nieco okrojonej postaci można je uznać za emblematyczne. Szczególnie, że warstwa obrazowa wszystkich godeł impresorskich zaliczanych do tej kategorii była najczęściej wierną kopią ilustracji (czyli iconów) zdobiących konkretne emblemy. Wyraźne koneksje emblematyczne wykazują znaki firmowe oficyn należących m.in. do Mateusza Siebeneichera, jego syna Jakuba, Akademii Zamojskiej oraz Szymona Kempiniego ${ }^{32}$;

5) sygnety o wymowie religijnej, czyli te, w których motywy przedstawieniowe, mające zazwyczaj charakter symboliczny, przesycone są treściami religijnymi. W poczet tego typu znaków - popularnych szczególnie w dobie kontrreformacji - zaliczyć można m.in. godło oficyny Jana Wolraba i jego dziedziców z wyobrażeniem pelikana w roli głównej, a także Stanisława Murmeliusa z wyciągniętą w górę dłonią dzierżącą serce ${ }^{33}$. Jako swoistą podgrupę wydzielić należy z tej kategorii sygnety o treściach inspirowanych Talmudem, jedną z ważniejszych ksiąg religii judaistycznej, z której motywy do swych godeł firmowych czerpali pracujący na ziemiach polskich typografowie żydowscy, wśród nich: Icchak ben Aaron Prostic, Kalonimos ben Mordechaj Jafe i jego wnuk Cwi ben Kalonimos Jafe ${ }^{34}$.

${ }^{30}$ Podobną kategorię sygnetów drukarskich wydzielił również Heinrich Grimm, określając ją mianem Theologische Symbole und Heiligen-Darstellungen als Druckerzeichen. Zob. H. Grimm, op.cit., s. 54-76.

${ }^{31}$ K. Krzak-Weiss, Polskie sygnety..., s. 109-112.

${ }^{32}$ Ibidem, s. 141-143, 173-176. Zob. również: P. Buchwald-Pelcowa, Emblematyczne koneksje sygnetu Mateusza Siebeneichera, „Biuletyn Biblioteki Jagiellońskiej” 1981, nr 1-2, s. 109-112; J. Kowalczyk, W kręgu kultury dworu Jana Zamoyskiego, Lublin 1980, s. 170-172; K. Krzak-Weiss, Jeszcze jeden polski sygnet o emblematycznych koneksjach (czyli kilka uwag o znaku firmowym Szymona Kempiniego), „Roczniki Biblioteczne” (52) 2008, s. 3-13.

${ }^{33}$ K. Krzak-Weiss, Polskie sygnety..., s. 146-147, 169-172.

${ }^{34}$ Ibidem, s. 151-152, 166-167, 187. Więcej na temat Talmudu i czerpanych zeń motywów zob. K. Pilarczyk, Talmud i jego drukarze w pierwszej Rzeczypospolitej. Z dziejów przekazu religijnego w judaizmie, Kraków 1998. 
Na koniec warto dokonać jeszcze jednej, całkowicie odmiennej od już przedstawionych, systematyzacji, która za podstawę porządkowania obiera kryterium natury typograficznej (związane ściśle z morfologią książki) odnoszące się do umiejscowienia sygnetu w obrębie druku. Dzięki przyjęciu tego kryterium całość obszernego materiału badawczego podzielić można wprawdzie tylko na dwie grupy: 1) znaki będące samodzielnymi kompozycjami w istocie niezależnymi od miejsca wytłoczenia; początkowo umieszczane na końcu druku, zazwyczaj w kolofonie (il. 2), a później również na karcie tytułowej lub w jej obrębie (tj. na odwrocie karty tytułowej, czyli na tzw. stronie redakcyjnej) oraz 2) znaki sytuowane tylko na karcie tytułowej i stanowiące z nią nierozerwalną całość; ale właśnie druga z tych grup daje sposobność wprowadzenia jeszcze jednego terminu typologicznego - sygnetu o charakterze bordiurowym. Konieczne jest jednak podkreślenie, że warunkiem sine qua non przeprowadzenia takiego podziału jest możliwość usytuowania godła w obu wskazanych miejscach druku, co w przypadku pierwszych sygnowanych książek nie mogło się zdarzyć. O ile bowiem kolofon istniał już w rękopisach, o tyle karta tytułowa stała się elementem typowym dopiero dla książek drukowanych, a proces jej formowania, choć zainicjowany około połowy XV stulecia, zakończył się dopiero u jego schyłku ${ }^{35}$. $\mathrm{W}$ pierwszych latach istnienia i stosowania sygnetu drukarskiego nie było zatem dlań innego miejsca jak tylko kolofon - tam właśnie umieścili swój znak firmowy jego pomysłodawcy - Fust i Schöffer. Gdy jednak karta tytułowa w pełni się wykształciła, stała się dla godła równie atrakcyjna, jeśli nawet nie atrakcyjniejsza, lokalizacja, bo zdecydowanie lepiej sprawdzała się w roli miejsca dla reklamy oficyny wydawniczej. Funkcję tę karta tytułowa mogła zaś pełnić tym skuteczniej, im ciekawsza i bardziej przyciaggająca uwagę czytelnika była jej dekoracja. Połączenie bogatej ornamentyki obejmującej wszystkie marginesy zdobionej karty z sygnetem typografa było zatem rozwiązaniem idealnym i właśnie tego typu zespolenia określić można mianem sygnetów o charakterze bordiurowym. Znak firmowy impresora przybierał w nich zazwyczaj postać tarczy herbowej z umieszczonymi nań monogramami właściciela warsztatu drukarskiego, stanowiącej immanentny komponent dekoracji bordiuralnej, która okalała kartę tytułową. Najlepszymi przykładami tego typu rozwiązań są m.in. godła Jana Hallera, Floriana Unglera, wdowy po nim - Heleny (il. 1) czy Macieja Szarfenberga ${ }^{36}$.

Zaprezentowana wielość i różnorodność typów, które można wyszczególnić w obrębie zespołu sygnetów drukarskich stosowanych przez pol-

${ }^{35} \mathrm{O}$ procesie wykształcania karty tytułowej zob. W. Roberts, op.cit., s. 48; H. Szwejkowska, op.cit., s. 68, 71-73; Encyklopedia wiedzy o ksiażze, szp. 1112-1113; K. Krzak-Weiss, Polskie sygnety..., s. 23-24.

${ }^{36}$ Ibidem, s. 108, 113-114, 121-122. 
skich typografów od XV do połowy XVII stulecia dowodzi bezsprzecznie, że jest to materiał złożony i niejednorodny, ale także frapujący dla badacza. Godne uwagi jest to, że znaki polskich impresorów wykazują wyraźne podobieństwo typologiczne do sygnetów używanych poza granicami Rzeczypospolitej. Nierzadko jest to zresztą o wiele więcej niż tylko podobieństwo, bo pośród mnogości rodzimych godeł nie brak takich, które stanowią kopie bądź daleko idące naśladownictwa kompozycji należących do zagranicznych mistrzów czarnej sztuki. Nie umniejsza to jednakże wartości polskich znaków, a wręcz przeciwnie - pozwala widzieć je jako część większego zespołu obejmującego godła firmowe wszystkich europejskich oficyn. Część może nieco słabszą artystycznie i niewybijającą się pod względem ikonograficznym, niemniej - bardzo istotną.

\section{KATARZYNA KRZAK-WEISS}

\section{The typology of printers' marks (with the example of printers' logotypes used by Polish printers from the 15th to the first half of the 17 century)}

Aвstract. This article provides the reader with an overview of the printer marks used by printing offices and printing houses in the Polish and Lithuanian Commonwealth from the fifteenth century to the first half of the seventeenth century, i.e. from the time when the colophon, including the printer's logotype, appeared in a Polish publication for the first time to the times when Polish typography was beset by a particularly pronounced crisis. The adopted chronological timeframe for the purpose of the article includes thus more than a hundred printers' marks, a large enough number to be attended with the appropriate clarification and classification.

A method that allows us to proceed with the task in a most clear way is to isolate individual types, which can be done in relation to particular adopted appropriate criteria. Appropriately, meaning in such a way so that they include each and every aspect of the matter under investigation and make it possible to present it in a most extensive way. In the case of printer marks, these criteria must primarily take into consideration the fact that the latter are not only typografic elements but graphical ones as well, which necessitates an approach in which they should be studied both in view of typography, or, more broadly of the study of the book, and also that of the graphical art. Taking it all into account, the rich and widely diversified group of Polish printer's marks used from the fifteenth century to the first half of the seventeenth century can be classified according to the three following criteria: chronological, iconographical and those related to the morphology of the book.

KEY wORDs: printer's mark, typology, Polish typography (15-17c.) 